\title{
PESSOAL
}

\section{A Formação e o Aperfeiçoamento dos Quadros Administrativos de Chefia}

\author{
J. DE NAZARÉ T. DIAS
}

\begin{abstract}
$\mathrm{O}$
satistatório funcionamento da burocracia só pode ser conseguido mediante cuidadosa organização dos quadros administrativos de chefia. Sem um corpo de direção bem constituído e sujeito a contínuo processo de aperfeiçoamento, as diretrizes administrativas, formuladas pelos poderes competentes do regime democrático, têm sua implementação prejudicada pelo emperramento da máquina burocrática ou pela insensibilidade da mesma aos problemas sociais da hora presente.
\end{abstract}

A verdade dêste conceito é reconhecida por todos os países que dispõem de serviços civis organizados. Vejamos o que ocorre no serviço civil federal brasileiro.

Fôrça é reconhecer, vendo as coisas com realismo, que o problema ainda não mereceu entre nós a devida atenção. Bem que se reconhecem as grandes deficiências da nossa burocracia, sem que isso, todavia, chegue a constituir-se em preocupação dominante dos governos ou dos legisladores, talvez pela falta de pressão dos contribuintes, que se mostram, no Brasil, lamentàvelmente omissos em exigir a boa e econômica aplicação da receita pública em despesas de pessoal e na organização racional dos serviços públicos. Temos preferido permanecer em atitude meramente contemplativa, limitando-nos a reconhecer a existência dos males e a profligá-los. Continuamos a depositar execessiva confiança na capacidade brasileira de improvisação, numa época em que são por demais conhecidos os métodos de administração científica.

Os quadros administrativos de chefia, compreendendo, nos diversos níveis funcionais, as denominadas atividades de administração geral (pessoal, orçamento, contabilidade, material, etc.), as atividades de Fazenda e Tesouro e cutras, predominantemente, de caráter administrativo, devem ser formados mediante recrutamento, para os postos iniciais da escala hierárquica de chefias, de elementos dotados de apurada inteligência e que revelem aptidão para o futuro exercício de lugares de comando e superior coordenação administrativa. Recrutados êsses elementos pelos processos tècnicamente mais indicados, há que desenvolvê-los no serviço do Estado e prepará-los, através dos variados métodos de treinamento conhecidos, para os quadros de direção da burocracia. O problema oferece, portanto, dois aspectos distintos: o de recrutamento, quando se procura atrair para os postos iniciais elementos humanos 
promissores; e o de treinamento, que visa ao aperfeiçoamento constante dos elementos recrutados sob aquela inspiração, preparando-os, gradativamente, para o acesso aos diversos escalões da linha de chefia.

Atualmente, o recrutamento para os postos iniciais pode ser criticado por não levar em conta o futuro aproveitamento dos candidatos em postos de grande relêvo na vida administrativa do país. Não se trata, porém, de mal irremediável, mesmo porque entre o pessoal assim recrutado há elementos potencialmente capazes de atingir os referidos postos. Mas é notória a lamentável ausência de preocupação de treinamento funcional para os postos de chefia. Sem dúvida, o atual regime de chefias em comissão, sob a forma de cargos em comissão ou de funções gratificadas, não cria ambiente propício ao fim colimado. Isso não basta, no entanto, para explicar e muito menos justificar a despreocupação do Legislativo e do Executivo por questão realmente vital para a eficiência da administração pública federal. Ainda porque seria lícito, dentro do sistema atual de constituição dos quadros, condicionar o provimento dos postos de chefia, mantido embora o caráter de comissão, à proveitosa conclusão dos programas de treinamento traçados; e a permanência em tais funções ao constante aperfeiçoamento dos servidores investidos de tão importantes atribuições.

Custa crer que os Poderes Públicos venham revelando tal desinterêsse por êste relevante problema. Confronte-se, a respeito, a situação brasileira com a da Inglaterra e da França. Na Inglaterra, pode-se afirmar que a reforma do serviço civil, em fins do século passado, visou, precipuamente, à instituição de um corpo administrativo de elite - a "Administrative Class" capacitado para dirigir e por em funcionamento a complexa engrenagem burocrática inglesa. Na França, ao afirmar-se, em 1945, após a liberação, o imperativo de reforma do serviço civil, a formação de quadros administrativos dirigentes de elite constituiu-se, de imediato, numa das mais sérias preocupações, corporificada, mais tarde, na criação da Escola Nacional de Administração. Comprovam essas duas grandes nações o princípio de que uma administração estável e eficiente, sujeita a códigos éticos rigorosos, pode suportar governos instáveis, sem maiores abalos para a vida do país e sem prejudicar os serviços que cabe à burocracia prestar à população, como é exemplo eloqüente a França, sujeita, depois de 1946, a permanente instabilidade nos seus quadros de direção política. E, na Inglaterra, o respeitado "Civil Service" enfrentou, recentemente, com notável êxito, o teste da entrega da direção politica do país, sucessivamente, aos Conservadores, aos Trabalhistas e aos Conservadores.

Mas não precisamos, de modo algum, buscar o exemplo estrangeiro, pois aqui mesmo encontramos soluções sensatas e eficazes. Na verdade, são notórios os esforços despendidos para disciplinar a formação e o aperfeiçoamento de elites dirigentes militares, através de recrutamento adequado e de cursos sistemáticos, que se sucedem na escala hierárquica e sem os quais o militar não pode ter aceso aos postos mais elevados do oficialato. O resultado dessa acertada orientação é a comprovada existência de uma elite militar tècnicamente equipada para os misteres de comando e direção das forças armadas. 
Já é tempo de dedicar-se mais atenção a êste problema essencial, que responde, em grande parte, pela ineficiência e descoordenação da ação burocrática, e, o que é mais importante, pela descontinuidade administrativa, vício fundamental da administração brasileira. Não se pode, ao menos, alegar que haja falta de recursos para êsse fim, pois êles existem - e até com certa abundância - no orçamento, cumprindo apenas evitar que se diluam e desperdicem em variadas iniciativas de treinamento, de proveito questionável quando se consideram as reais necessidades do serviço civil federal. O que se impõe é traçar programa capazes de produzir os resultados almejados, o mais ràpidamente possível.

As iniciativas, nesse esntido, terão de partir dos altos poderes da República, hão de fluir do tôpo da administração, pois cabe, indubitàvelmente, aos dirigentes políticos, eleitos, pelo povo no Legislativo ou no Executivo, dar expressão aos anseios populares de ser a comunidade servida por uma organização burocrática eficientemente dirigida.

O Plano de Classificação de Cargos representa uma tendência no sentido certo. Mas, sejamos mais uma vez realistas: sem o programa para o qual chamamos a atenção dos dirigentes políticos do país, a execução do Plano de Classificação de Cargos encontrará dificuldades insanáveis.

\section{SUMMARY}

A careful organization of the class of administrative heads, every member of which subject to a permanent process of self-development, as essential to the carrying out of public policy. The necessity recognized in theory but not translated into a practical prosramme for the recruitment and training of prospective administrative heads. Present-day situation as an expression of the over-confidence on improvization and absence of taxpayers pressure towards a better utilization of budgetary funds for personnel administration and for the rational organization of the civil service.

Recruitment of potential administrative heads to be based on the selection of appli. cants of high intelligence and aptitude for eventual administrative leadership. The necessity of a functional in-service training programme for candidates inducted.

The prevailing system of temporary tenure of administrative heads as a disadvantage. Yet the successful completion of training programmes should be required from them. Permanence of tenure, if adopted, to be conditioned by constant self-development.

The "administrative class" in the British civil service and the "élite" in the French public administration as contrasted with the Brazilian situation. The preparation of mili. tary leaders in Brazil as an example to be followed in the civil service; the adequate re. cruitment and training programme offered to military officers; the completion of specific courses entitling for promotion to higher ranks.

The availability of budgetary funds for the proposed programme. Initiative to be expected only from the highest level of the Administration.

The Position Classification Plan under consideration of the Congress as a step in the sight direction although liable to meet unsurmountable obstables if the lack of competent administrative leadership is to prevail. 